\title{
Epidemiology of Influenza in Fars Province, Southern Iran; a Population-Based Study (2015-2019)
}

\author{
Hossein Faramarzi, MD; Razieh Sadat Mousavi-Roknabadi, MD²; Abdolrasoul Hemmati, Phram D³; Ali Faramarzi'; Hamid Bakhtiari, MD \\ ${ }^{1}$ Department of Community Medicine, School of Medicine, Shiraz University of Medical Sciences, Shiraz, Iran \\ ${ }^{2}$ Department of Emergency Medicine, Faculty of Medicine, Shiraz University of Medical Sciences, Shiraz, Iran \\ ${ }^{3}$ Vice-Chancellor of Health Affairs, Non-Communicable Diseases Research Center, Shiraz University of Medical Sciences, Shiraz, Iran \\ ${ }^{4}$ Student Research Committee, Shiraz University of Medical Sciences, Shiraz, Iran \\ ${ }^{5}$ Department of Communicable Disease Control, Vice Chancellor of Health, Shiraz University of Medical Sciences, Shiraz, Iran
}

\begin{abstract}
Background: Influenza is one of the most important viral diseases with high mortality and morbidity that can have a great impact on public health and economy.

Objective: To investigate the clinical and epidemiological features of influenza virus $\mathrm{A} / \mathrm{H} 1 \mathrm{~N} 1, \mathrm{~A} / \mathrm{H} 3 \mathrm{~N} 2$, and $\mathrm{B}$ infection in Fars province, southern Iran, in 2015-2019.

Methods: In this retrospective cross-sectional study, we assessed the archived data of Syndromic Surveillance System of Iran's Health Ministry, allowed access by Communicable Diseases' Unit of Health chancellor of Shiraz University of Medical Sciences, from December 22, 2015 to September 22, 2019. The participants included all patients whose data were recorded as influenza-like illness (ILI) and severe acute respiratory infections/illness (SARI). Influenza viral infection was confirmed by reverse-transcriptase polymerase chain reaction (RT-PCR).

Results: Totally, 1269 patients suspected of influenza were sampled. The mean \pm SD of age was $29.40 \pm 26.91$ years. Fever was the most common symptom $(68.6 \%)$. The highest incidence was in winter $(55.9 \%)$. Of 928/1269 laboratory's results which were recorded in the registry, 204 (16.08\%) samples were positive and 724 (57.05\%) were negative. Among 204 positive results, 191 $(15.05 \%)$ were influenza type A, and $8(0.63 \%)$ influenza type B. Among patients with definite influenza type A, $34(2.68 \%)$ had H1N1/p subtype, $58(4.57 \%) \mathrm{H} 3 \mathrm{~N} 2$, and one $(0.08 \%)$ had other subtypes; however, subtypes were not identified in $7.72 \%$ of patients. Six (3.0\%) patients with confirmed influenza expired.

Conclusion: The incidence of influenza, especially type A, in Fars province, southern Iran is considerable and requires more attention for prevention in health policy programs.

Keywords: Influenza, Influenza A, Influenza A/H3N2, Influenza A/H1N1, Influenza B

Cite this article as: Faramarzi $\mathrm{H}$, Mousavi-Roknabadi RS, Hemmati A, Faramarzi A, Bakhtiari H. Epidemiology of influenza in Fars province, Southern Iran; a population-based study (2015-2019). Arch Iran Med. 2021;24(3):199-208. doi: 10.34172/aim.2021.31.
\end{abstract}

Received: February 27, 2020, Accepted: January 2, 2021, ePublished: March 1, 2021

\section{Introduction}

Influenza is one of contagious viral diseases caused by an RNA virus from the Orthomyxoviridae family. ${ }^{1}$ Through pandemics, epidemics, outbreaks, and sporadic cases, influenza causes high mortality, puts more people at risk of serious complications, and causes immunity in a huge number of individuals. ${ }^{2}$ Three types of influenza are known in which two types of superficial glycoproteins, $\mathrm{NA}$ and HA, exist in types A and B, while influenza C has only one glycoprotein on its surface. Totally, 16 types of $\mathrm{H}$ and 9 types of $\mathrm{N}$ antigens are identified of which $\mathrm{A} / \mathrm{H} 1 \mathrm{~N} 1$ is the most common. ${ }^{3}$ The epidemiological patterns of these three types of influenza differ markedly. Influenza $C$ virus does not cause epidemics, but makes mild respiratory infections sporadically. Influenza B virus sometimes causes epidemics, and pandemics are mostly caused by type $\mathrm{A}$. Types $\mathrm{B}$ and $\mathrm{A} / \mathrm{H} 1 \mathrm{~N} 1$ were the most prevalent viruses worldwide in recent years, and $\mathrm{H} 3 \mathrm{~N} 2$ is on the rise. ${ }^{4-6}$ Diagnosis is usually based on epidemiological characteristics. It should be noted that the economic impact of influenza outbreaks is of great importance. ${ }^{6}$ The influenza virus infection has different clinical features, and it may not be distinguished from other respiratory viral diseases. So, it is not detectable based solely on symptoms.? Correct diagnosis and rapid and appropriate management are important for controlling this disease, which would not be possible without practical laboratory tests. ${ }^{8}$ Various tests are available for rapid antigen detection, but confirmation of the influenza viral infection by reverse-transcriptase polymerase chain reaction (RT-PCR) ${ }^{6}$ is rapid, costeffective, sensitive and specific. ${ }^{8-10}$ All positive cases should be considered as influenza, and specific treatment should be started as soon as possible. This is crucial in controlling epidemics. ${ }^{11}$

\section{Objective}

Because of the importance of this disease, and the need for information about its epidemiology for public health 
action planning to prevent and control the disease, the aim of the current study was to investigate the clinical and epidemiological features of the influenza virus $\mathrm{A} / \mathrm{H} 1 \mathrm{~N} 1$, A/H3N2, and B infection in Fars province, southern Iran from 2015 to 2019.

\section{Materials and Methods}

In this retrospective cross-sectional study, we assessed the archived data of Syndromic Surveillance System of Iran's health ministry, allowed access by Communicable Diseases' Unit of Health chancellor of Shiraz University of Medical Sciences.

The participants included all patients who were referred to one of the health centers in Fars province and their data were recorded as influenza-like illness (ILI) and severe acute respiratory infections/illness (SARI) from December 22, 2015 to September 22, 2019.

ILI is defined as incidence of fever and cough symptoms during the recent week. SARI is defined as fever and cough during the recent week, and hospitalization due to one of the symptoms interfering with the functioning of one of three vital body systems including: 1. respiratory system (tachypnea, or intercostal muscle depression during breathing, or breathing with sound, or bloody sputum), or 2. cardiovascular system (chest pain, or severe hypotension, or rhythmic disorder), or 3. nervous system (decreased consciousness, or seizures). A suspected case of influenza was defined as: fever above $38^{\circ} \mathrm{C}$, or having at least two respiratory symptoms (including rhinorrhea, sore throat or cough) plus at least one of the following conditions: history of travel to an epidemic area during the last 7 days, or history of contact with an infected patient, or severe pulmonary disease or any unknown pulmonary disease causing death. Influenza viral infection is confirmed by RT-PCR. ${ }^{8}$

Two types of data were collected: (a) demographic information (age, gender, the place of residence, the season and month of the disease) and (b) clinical and laboratory findings (symptoms, past medical history, type of viruses, comorbidities, and the patients' status). We checked for data duplication, as well as the validity of data, or if there is strange data or not. For example, before conducting the statistical analysis, the variable of age was recorded as the year of birth in some patients, so we converted it to age. Uncomplete data were considered in the statistical analysis and were recorded as not determined.

All analyses were performed using the SPSS software version 22.0 for Windows, using chi-square and Fisher's exact tests for proportions, and independent $t$ and one-way ANOVA tests for the means. The results were presented as mean \pm standard deviation (SD) for continuous variables and were summarized in number (percentage) for categorical variables. Two-sided $P<0.05$ and 95\% confidence interval (CI) were considered to be statistically significant. Microsoft Office Excel version 2013 for
Windows was used to create diagrams.

\section{Results}

During the study period, 1149124 patients were referred to 77 Fars province health centers, southern Iran, due to respiratory symptoms, and their data were recorded in the registry system. All 6966 (61\%) were suspected of ILI [3,287 (47.2\%) males vs. 3,679 (52.8\%) females]. Both genders were similar in terms of ILI and SARI $(P=0.425)$. The mean \pm SD of age was $32.69 \pm 26.44$ (range: $0-96$ ) $(31.9 \pm 27.09$ in males and $34.20 \pm 25.75$ in females, $P=$ $0.103,95 \% \mathrm{CI}=-6.85,0.63)$. Samples were taken from 387 patients with ILI, including 289 (74.87\%) throat swabs and $20(5.17 \%)$ nasal swabs. The results showed that $60(15.50 \%)$ patients had influenza type A and two $(0.52 \%)$ had influenza type B. Influenza type A subtype identification was done in 31 patients, of whom nine (2.33\%) had H1N1/p and 22 (5.68\%) H3N2.

As shown in Table 1, 1735 of the referred patients [841 (48.5\%) males and 894 (51.5\%) females, $P=0.794$ ] were suspected of SARI. The mean \pm SD of age was $31.28 \pm$ 27.99 (range: $0-96)$ years $(29.61 \pm 28.19$ in males and $32.85 \pm 27.73$ in females, $P=0.016,95 \% \mathrm{CI}=-5.87$, -0.61). Samples were taken from 882 patients with SARI, including 668 (75.74\%) throat swabs, 151 (17.12\%) endotracheal suctions, and 46 (5.21\%) nasal swabs, of which 138 (15.65) were positive and 550 (62.38\%) were negative. Totally, 131 (14.85\%) patients had influenza type A, and six $(0.68 \%)$ had influenza type B. Among patients with definite influenza type A, 25 (2.83\%) had the $\mathrm{H} 1 \mathrm{~N} 1 / \mathrm{p}$ subtype, $36(4.08 \%)$ the $\mathrm{H} 3 \mathrm{~N} 2$ subtype, and one $(0.11 \%)$ had other subtypes, but the subtypes were not identified in other patients.

In both ILI and SARI, the highest incidence was in winter, and the lowest in summer. As shown in Figures 1 and 2, the highest incidence pertained to JanuaryFebruary. In ILI, the disease was on a downward trend from February-March to June-July, followed by an upward trend that peaked in August-September, and then decreased. In the case of SARI, a small peak was seen in April-May.

In general, 1,269 patients suspected of influenza were sampled, including $957(75.41 \%)$ throat swabs, 151 (12.0\%) endotracheal suctions, and 66 (5.2\%) nasal swabs. The type of sampling was not recorded in other patients. The mean \pm SD of age was $29.40 \pm 26.91$ (range: $0-96)$ years [28.31 \pm 26.89 in males and $30.41 \pm 26.90$ in females, $P=0.94,95 \% \mathrm{CI}=1.511,-5.061]$. Both genders were sampled equally $(P=0.73)$. The highest incidence was observed in the age group of $0-1$ years $(23.6 \%)$, and the lowest in the age group of 15-24 years (6.0\%) (Table 2).

In these patients, fever was the most common symptom (68.6\%), and the most common comorbidity was chronic heart disease (14.1\%) followed by diabetes (7.6\%). 
Table 1. Patients' Characteristics With Influenza-Like Illness (ILI) or Severe Acute Respiratory Infections/IIIness (SARI) in Southern Iran (2015-2019)

\begin{tabular}{|c|c|c|}
\hline Variables & $\begin{array}{l}\text { Patients Suspected } \\
\text { of ILI }(n=6966)\end{array}$ & $\begin{array}{l}\text { Patients Suspected } \\
\text { of SARI }(n=1735)\end{array}$ \\
\hline Age $($ mean \pm SD) & $32.69 \pm 26.44$ & $31.28 \pm 27.99$ \\
\hline Male & $31.9 \pm 27.09$ & $29.61 \pm 28.19$ \\
\hline Female & $34.20 \pm 25.75$ & $32.85 \pm 27.73$ \\
\hline$P$ value & $\begin{array}{c}0.103(95 \% \mathrm{Cl}= \\
-6.85,0.63)\end{array}$ & $\begin{array}{c}0.016 *(95 \% \mathrm{Cl}= \\
-5.87,-0.61)\end{array}$ \\
\hline \multicolumn{3}{|l|}{ Age groups (\%) } \\
\hline $0-1$ & $525(7.53)$ & $413(23.8)$ \\
\hline $2-4$ & $569(8.17)$ & $99(5.7)$ \\
\hline $5-14$ & $966(13.86)$ & $162(9.3)$ \\
\hline $15-24$ & 769 (11.05) & $118(6.8)$ \\
\hline $25-34$ & $1128(16.20)$ & $193(11.1)$ \\
\hline $35-44$ & $872(12.53)$ & $173(10.0)$ \\
\hline $45-54$ & $682(9.78)$ & $126(7.3)$ \\
\hline $55-64$ & $569(8.17)$ & $170(9.8)$ \\
\hline$>65$ & $886(12.71)$ & $281(16.2)$ \\
\hline \multicolumn{3}{|l|}{ Gender (\%) } \\
\hline Male & $3287(47.2)$ & $841(48.5)$ \\
\hline Female & $3679(52.8)$ & $894(51.5)$ \\
\hline$P$ value & 0.425 & 0.794 \\
\hline \multicolumn{3}{|l|}{ Season of disease $(\%)$} \\
\hline Spring & $1245(17.9)$ & $295(17.0)$ \\
\hline Summer & $1500(21.5)$ & $80(4.6)$ \\
\hline Autumn & $1429(20.5)$ & $355(20.5)$ \\
\hline Winter & $2792(40.1)$ & 1005 (57.9) \\
\hline \multicolumn{3}{|l|}{ Laboratory sample (\%) } \\
\hline Total sample & 387 & 882 \\
\hline Throat swab & $289(74.87)$ & $668(75.74)$ \\
\hline Nasal swab & $20(5.17)$ & $46(5.21)$ \\
\hline Endotracheal suction & $0(0)$ & $151(17.12)$ \\
\hline Not determined & $78(20.16)$ & $17(1.93)$ \\
\hline \multicolumn{3}{|l|}{ Laboratory result (\%) } \\
\hline Positive & $66(17.05)$ & $138(15.65)$ \\
\hline Negative & $174(44.96)$ & $550(62.38)$ \\
\hline Not determined & 147 (37.98) & $194(22.0)$ \\
\hline \multicolumn{3}{|l|}{ Virus type (\%) } \\
\hline A & $60(15.50)$ & $131(14.85)$ \\
\hline $\mathrm{A}(\mathrm{H} 1 \mathrm{~N} 1 / \mathrm{p})$ & $9(2.33)$ & $25(2.83)$ \\
\hline $\mathrm{A}(\mathrm{H} 3 \mathrm{~N} 2)$ & $22(5.68)$ & $36(4.08)$ \\
\hline Other types & $0(0)$ & $1(0.11)$ \\
\hline Not determined & $29(7.49)$ & $69(7.82)$ \\
\hline B & $2(0.52)$ & $6(0.68)$ \\
\hline Not determined & $4(1.03)$ & $1(0.11)$ \\
\hline \multicolumn{3}{|l|}{ Patients' outcome (\%) } \\
\hline Outpatients & $6533(93.8)$ & $0(0)$ \\
\hline Inpatients & $433(6.2)$ & $1693(97.6)$ \\
\hline Death & $0(0)$ & $42(2.4)$ \\
\hline
\end{tabular}

Seventy (5.5\%) patients had a history of international travel; Iraq (3.9\%) and Saudi Arabia (0.9\%) were the most common. Besides, 43 patients (3.39\%) reported a history of domestic travel to other cities in Iran a week prior to the onset of symptoms. Also, 38 (2.99\%) patients reported a history of contact with birds. Pneumonia (29.7\%) was the most common complication.

Also, the highest incidence of influenza was in winter. The influenza had an upward trend that peaked in
December-January and January-February, and then decreased. The number of patients had a small increase in August-September (Figure 3).

Of the 928 laboratory results which were recorded in the registry system, 204 (16.08\%) samples were positive and 724 (57.05\%) were negative. Among the positive results, $191(15.05 \%)$ were influenza type A, and $8(0.63 \%)$ were influenza type B. In five patients, the virus type was not determined. Among patients with definite influenza type A, $34(2.68 \%)$ had the H1N1/p subtype, 58 (4.57\%) the $\mathrm{H} 3 \mathrm{~N} 2$, and one $(0.08 \%)$ had the other subtypes; subtypes were not identified in $98(7.72 \%)$ patients.

As shown in Table 3 , there was no statistically significant difference between the patients with confirmed influenza type A and B in terms of age, gender, history of travel, contact with birds, comorbidities, complications, or outcome. The mortality rate was similar in patients with influenza $\mathrm{A}$ and $\mathrm{B}(P=0.578)$. It was found that all patients with confirmed virus type $A$ had complications of primary and secondary pneumonia, cardiopulmonary, acute respiratory distress syndrome (ARDS), as well as bronchitis, and the most common complication was pneumonia. But only one patient (12.5\%) with confirmed virus type $\mathrm{B}$ had pneumonia, and other complications were not seen.

According to Table 4, there was an association between complications and gender $(P=0.011)$, and cardiopulmonary was mostly observed in male patients $(P=0.002)$ with unconfirmed influenza. Pneumonia and bronchitis were mostly found in the age group $0-1$ years $(P$ $<0.0001)$. There was no significant relationship between the complications and other factors. The most commonly prescribed drugs were ceftriaxone (28.6\%) and vancomycin (35\%). There was no significant statistical association between complications and gender, age groups, history of international and domestic travel, as well as history of contact with birds in patients with confirmed influenza virus type A and B (Supplementary file 1, Table S1).

Totally, $6(3.0 \%)$ patients with confirmed influenza died, and the age group of 35-44 years had the highest rate of mortality (66.7\%). There was a significant association between patients' outcome and age group $(P=0.036)$ (Table 5).

\section{Discussion}

In the current study, we investigated the clinical and epidemiological features of influenza virus $\mathrm{A} / \mathrm{H} 1 \mathrm{~N} 1, \mathrm{~A} /$ $\mathrm{H} 3 \mathrm{~N} 2$, and $\mathrm{B}$ infection among patients in Fars province, southern Iran, 2015-2019. The results showed that suspected influenza was more prevalent in the age group of $0-1(23.6 \%)$ and $>65$ years $(13.8 \%)$, but confirmed influenza was more prevalent in the age group of $>65$ (18.1\%) and 25-34 years (14.6\%).

Contrary to the present study, in which no difference was observed in the gender of patients with influenza, 


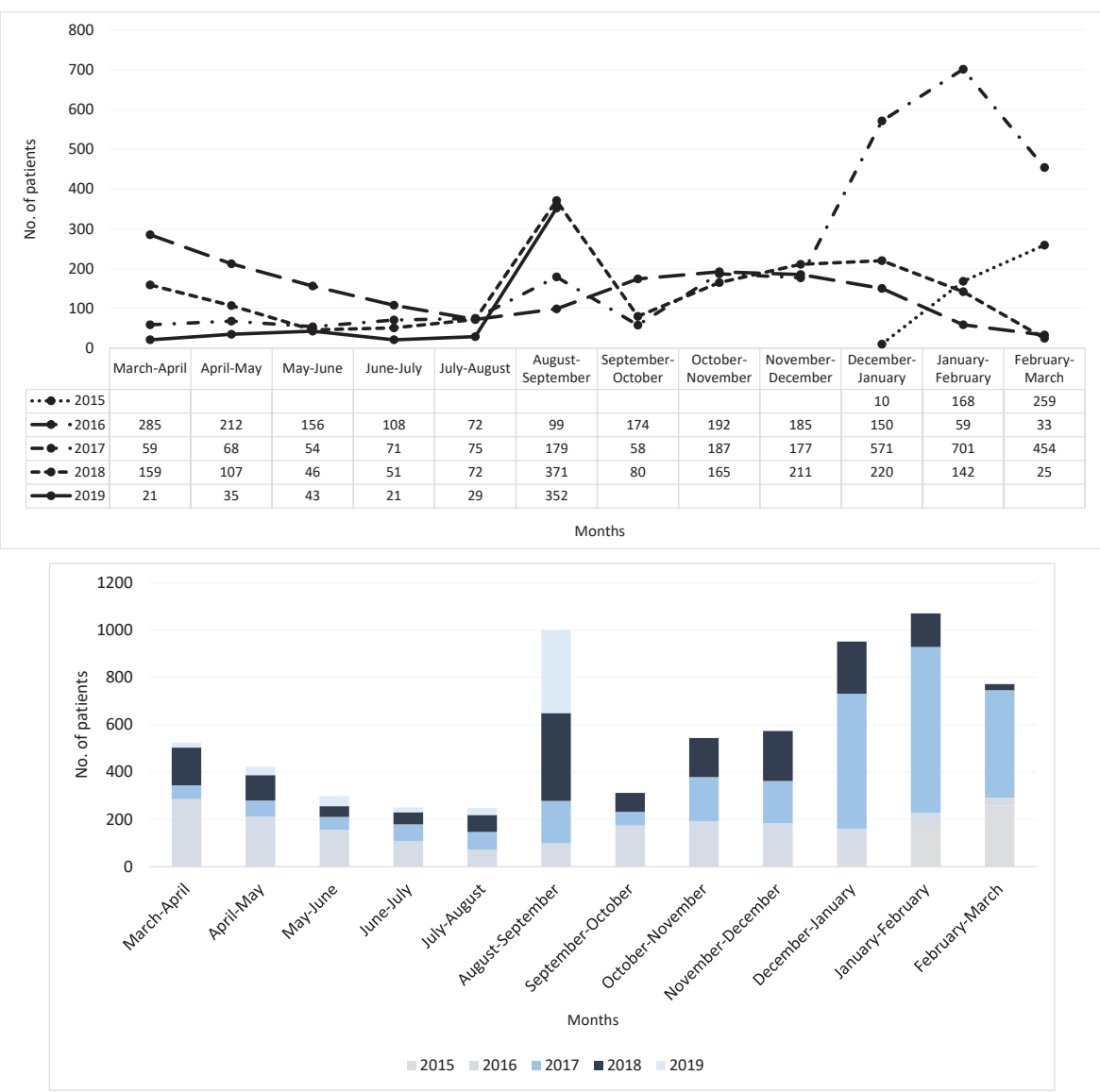

Figure 1. Annual Trend of Influenza-Like Illness (ILI) in Southern Iran (2015-2019).
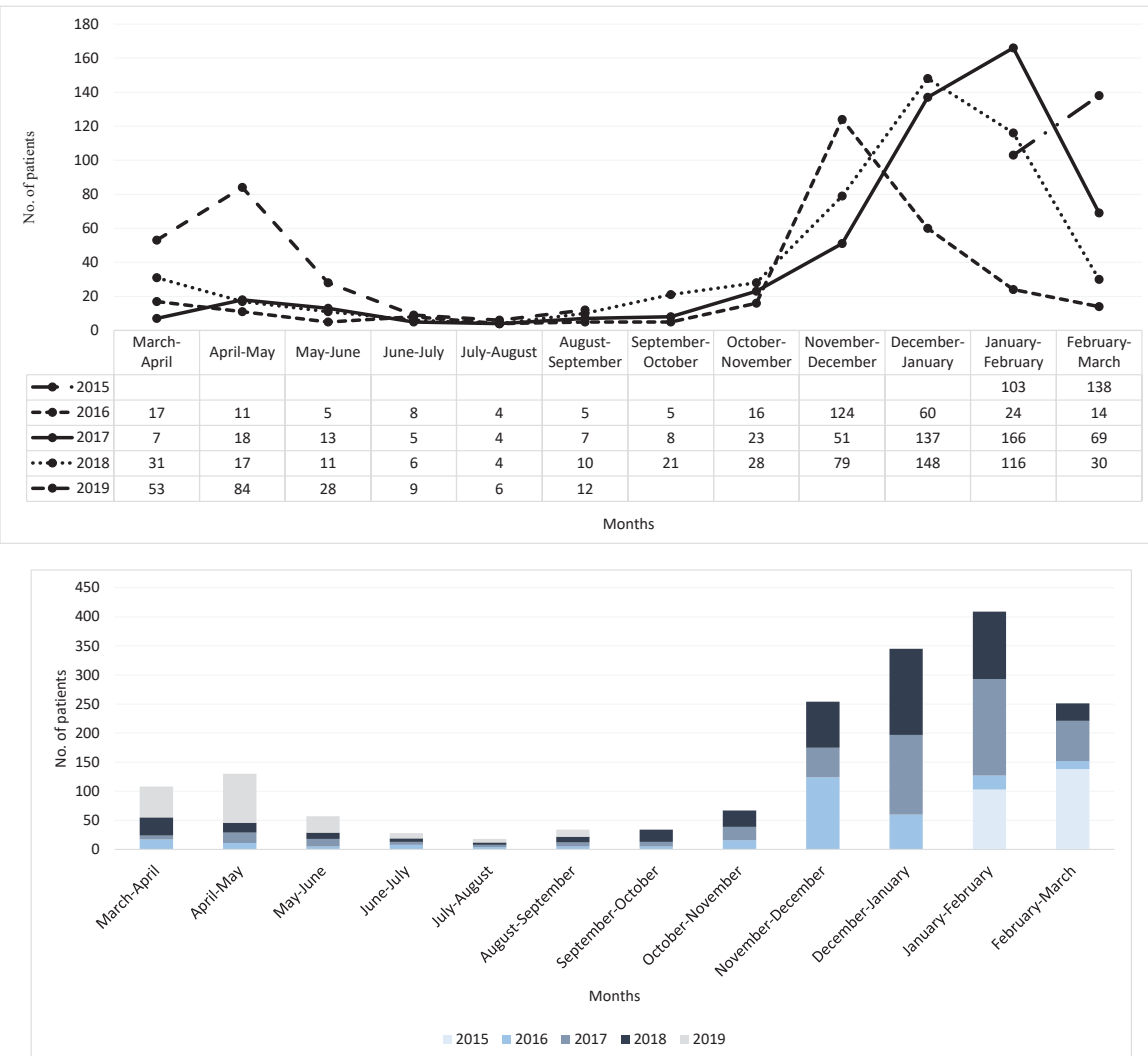

Figure 2. Annual Trend of Severe Acute Respiratory Infections/IIIness (SARI) in Southern Iran (2015-2019). 
Table 2. Characteristics of Patients Suspected of Influenza with Influenza Sample Test (Unconfirmed) in Southern Iran (2015-2019)

\begin{tabular}{|c|c|}
\hline Variables & $\begin{array}{l}\text { Patients with Influenza Sample } \\
\text { Test (Unconfirmed) }(n=1269)\end{array}$ \\
\hline Age $($ mean $\pm \mathrm{SD})$ & $29.40 \pm 26.91$ \\
\hline Male & $28.31 \pm 26.89$ \\
\hline Female & $30.41 \pm 26.90$ \\
\hline$P$ value & $0.94(95 \% \mathrm{Cl}=1.511,-5.061)$ \\
\hline \multicolumn{2}{|l|}{ Age groups $(\%)$} \\
\hline $0-1$ & $299(23.6)$ \\
\hline $2-4$ & $86(6.8)$ \\
\hline $5-14$ & $132(10.4)$ \\
\hline $15-24$ & $76(6.0)$ \\
\hline $25-34$ & $168(13.2)$ \\
\hline $35-44$ & $131(10.3)$ \\
\hline $45-54$ & $87(6.9)$ \\
\hline $55-64$ & $115(9.1)$ \\
\hline$>65$ & $175(13.8)$ \\
\hline \multicolumn{2}{|l|}{ Gender (\%) } \\
\hline Male & $613(48.3)$ \\
\hline Female & $656(51.7)$ \\
\hline$P$ value & 0.73 \\
\hline \multicolumn{2}{|l|}{ Season of disease $(\%)$} \\
\hline Spring & $220(17.3)$ \\
\hline Summer & $83(6.5)$ \\
\hline Autumn & $257(20.3)$ \\
\hline Winter & 709 (55.9) \\
\hline \multicolumn{2}{|l|}{ Months of disease (\%) } \\
\hline March-April & $82(6.5)$ \\
\hline April-May & $73(5.8)$ \\
\hline May-June & $65(5.1)$ \\
\hline June-July & $29(2.3)$ \\
\hline July-August & $12(0.9)$ \\
\hline August-September & $42(3.3)$ \\
\hline September-October & $27(2.1)$ \\
\hline October-November & $86(6.8)$ \\
\hline November-December & $144(11.3)$ \\
\hline December-January & $260(20.5)$ \\
\hline January-February & $298(23.5)$ \\
\hline February-March & $151(11.9)$ \\
\hline \multicolumn{2}{|l|}{ History of travel (\%) } \\
\hline International & $70(5.5)$ \\
\hline Domestic & $43(3.39)$ \\
\hline History of contact with birds (\%) & $38(2.99)$ \\
\hline \multicolumn{2}{|l|}{ Associated symptoms (\%) } \\
\hline Fever & $871(68.6)$ \\
\hline Dyspnea & $395(31.1)$ \\
\hline Sore throat & $357(28.1)$ \\
\hline Hypotension & $298(23.5)$ \\
\hline Cough & $281(22.1)$ \\
\hline Hemoptysis & 239 (18.8) \\
\hline Chest discomfort & 138 (10.9) \\
\hline \multicolumn{2}{|l|}{ Comorbidities (\%) } \\
\hline Chronic heart diseases & $179(14.1)$ \\
\hline Diabetes & $97(7.6)$ \\
\hline Chronic pulmonary diseases & $70(5.5)$ \\
\hline Chronic nervous diseases & $57(4.5)$ \\
\hline Chronic kidney diseases & $44(3.5)$ \\
\hline Pregnancy & $41(3.2)$ \\
\hline Malignancy & $27(2.1)$ \\
\hline Chronic liver diseases & $20(1.6)$ \\
\hline Chronic blood diseases & $16(1.3)$ \\
\hline Severe obesity & $15(1.2)$ \\
\hline Malnutrition & $3(0.2)$ \\
\hline HIV/AIDS & $3(0.2)$ \\
\hline Without underlying diseases & $817(64.4)$ \\
\hline
\end{tabular}

Table 2. Continued

\begin{tabular}{|c|c|}
\hline Variables & $\begin{array}{l}\text { Patients with Influenza Sample } \\
\text { Test (Unconfirmed) }(n=1269)\end{array}$ \\
\hline \multicolumn{2}{|l|}{ Laboratory sample (\%) } \\
\hline Total sample & 1269 \\
\hline Throat swab & $957(75.41)$ \\
\hline Nasal swab & $66(5.20)$ \\
\hline Endotracheal suction & $151(12.0)$ \\
\hline Not determined & $95(7.49)$ \\
\hline \multicolumn{2}{|l|}{ Laboratory result (\%) } \\
\hline Positive & $204(16.08)$ \\
\hline Negative & $724(57.05)$ \\
\hline Not determined & $341(26.87)$ \\
\hline \multicolumn{2}{|l|}{ Virus type (\%) } \\
\hline A & $191(15.05)$ \\
\hline $\mathrm{A}(\mathrm{H} 1 \mathrm{~N} 1 / \mathrm{p})$ & $34(2.68)$ \\
\hline $\mathrm{A}(\mathrm{H} 3 \mathrm{~N} 2)$ & $58(4.57)$ \\
\hline Other types & $1(0.08)$ \\
\hline Not determined & $98(7.72)$ \\
\hline B & $8(0.63)$ \\
\hline Not determined & $5(0.39)$ \\
\hline \multicolumn{2}{|l|}{ Complications (\%) } \\
\hline Pneumonia & $377(29.7)$ \\
\hline ARDS & $84(6.6)$ \\
\hline Cardiopulmonary & $62(4.9)$ \\
\hline Bronchitis & $55(4.3)$ \\
\hline Neurologic & $39(3.1)$ \\
\hline Without complications & $769(60.6)$ \\
\hline \multicolumn{2}{|l|}{ Patients' outcome (\%) } \\
\hline Outpatients & $387(30.5)$ \\
\hline Inpatients & $848(66.8)$ \\
\hline Death & $34(2.7)$ \\
\hline
\end{tabular}

Javid Khojasteh et al, in their study on the prevalence of influenza $\mathrm{A} / \mathrm{N} 1 \mathrm{H} 1$ in the Guilan province, north of Iran, showed that most patients were females with a mean age of 40 years. The highest prevalence in their study pertained to the age group of 10-20 years, which is not consistent with the results of the present study. ${ }^{12}$ Also, Haghshenas et al showed that the age group of 21-30 years constituted more than $50 \%$ of influenza $\mathrm{A} / \mathrm{H} 3 \mathrm{~N} 2$ patients in the Guilan province from 2011 to $2013 .{ }^{13}$ Rahmanian et al, showed that the age group of 15-40 years constituted the most influenza cases in Jahrom, Iran, ${ }^{14}$ and Yavarian et al reported that the highest prevalence pertained to the age group of 20-49 years, which is not in line with the results of the current study. ${ }^{15}$ Ling et al in Singapore reported that the majority of the patients belonged to the age group of $38-91$ years with a mean age of $91,10 \%$ of whom were males. ${ }^{16}$ In a study by Afrasiabian et al, a similar mean age was reported in patients with influenza. ${ }^{8}$ The incidence of influenza at the two ends of the age range may be due to a weak immune system; these two age groups need more surveillance and follow-up during an outbreak.

Influenza epidemics mostly occur during winter in temperate regions and during the rainy months of the year in tropical regions, but seasonal trends in epidemics are 


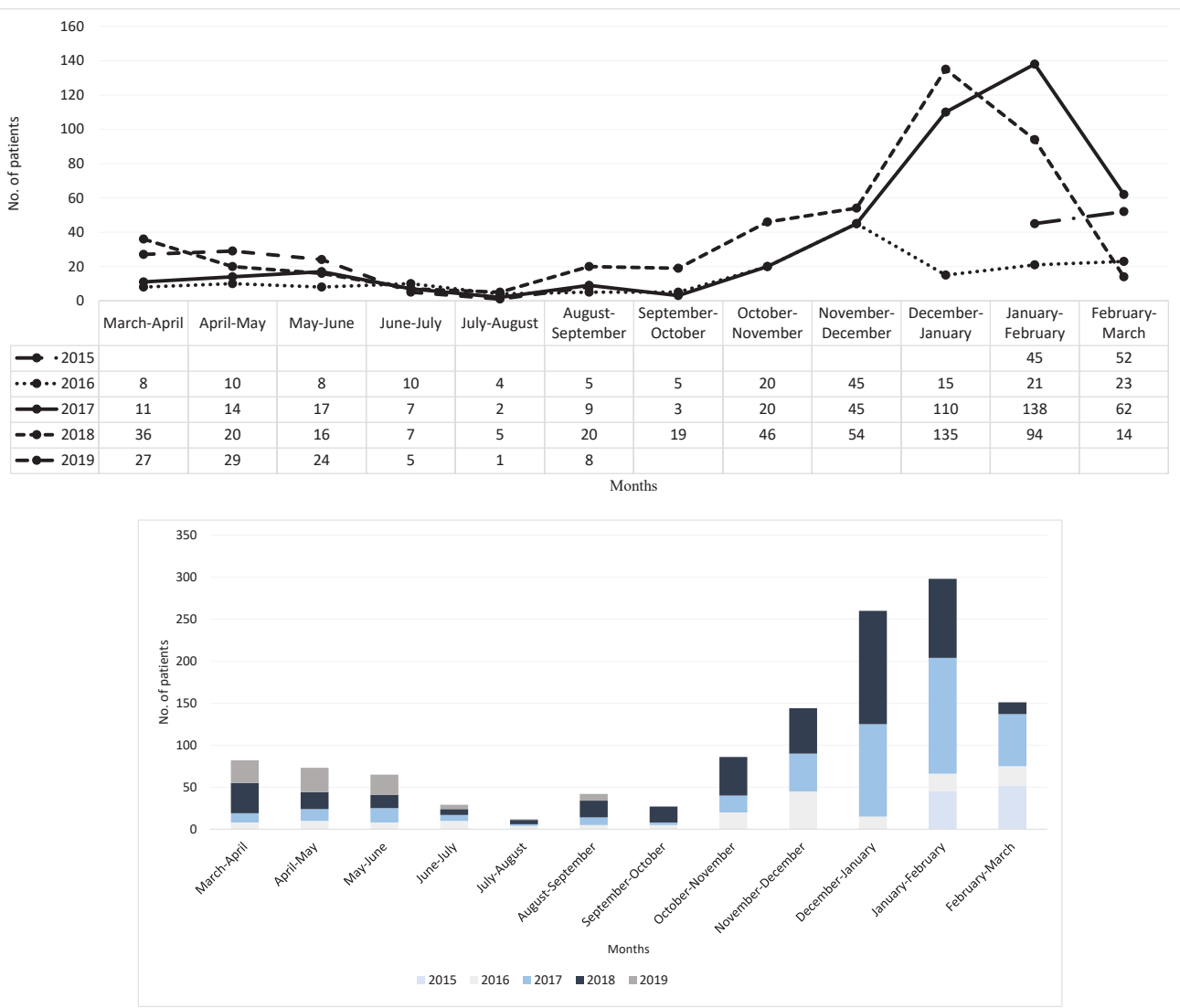

Figure 3. Annual Trend of Unconfirmed Influenza in Southern Iran (2015-2019).

not always constant, and sporadic cases or outbreaks may occur at any place regardless of the season. ${ }^{17}$ For example, Zaman et al stated that influenza activity is seasonal and in Bangladesh, most positive samples occurred from June to September. ${ }^{18}$ Our results showed that between March-April and June-July, influenza had a decreasing trend, followed by an increase in December-January and January-February (in winter) that reached its peak and then declined. The number of patients had a small increase in AugustSeptember. During the study years, the majority of the cases occurred in winters. The findings of Moghaddami et al showed that influenza had two waves; one about a month after the emergence of the disease, and the other, about one month after the reopening of schools. The first peak was predominantly among adults with a history of international travel, while the second was predominantly among school students. ${ }^{19}$ Moasser et al also showed that most cases occurred in February and March. ${ }^{20}$ Gouya et al reported that influenza is on the rise in the second half of the year coinciding with the reopening of schools and universities. ${ }^{21}$ Belderok et al showed that traveling has an effect on the epidemiology of influenza. ${ }^{23}$

Also, our results indicated a downward trend for ILI from February-March to June-July, reaching a peak in AugustSeptember, and then decreasing. After that, it is followed by an upward trend that peaks in January-February. In SARI, a small peak was seen in May. A total of $17.05 \%$ of the ILI patients and $15.65 \%$ of the SARI were positive for influenza. As influenza virus is one of the most important causes of ILI and SARI, ${ }^{22}$ the peak in September may be due to the start of the cold season and also increases in travels to this province, as well as preparing for schools and universities, and after that, it decreases with the start of influenza vaccination and development of herd immunity.

Ziyaeyan et al showed that the frequency of influenza type A in Shiraz, Iran was 4.2\%. ${ }^{24}$ Haghshenas et al showed that the frequency of influenza type B in the Mazandaran Province, northern Iran was 5.58\% from 2011 to $2013 . .^{25}$ Javid et al reported the prevalence of $\mathrm{A} / \mathrm{H} 1 \mathrm{~N} 1, \mathrm{~A} / \mathrm{H} 3 \mathrm{~N} 2$, and $\mathrm{B}$ influenza at $2.7 \%, 2.8 \%$, and $3.2 \%$, respectively in the Golestan Province, Iran from 2010 to 2014. ${ }^{11}$ In the study by Afrasiabian et al, A/H1N1 was confirmed in $14.8 \%$ of the patients. ${ }^{8}$ Mozhgani et al, in a metaanalysis on the prevalence of influenza in the Middle East, reported an overall prevalence of $10.2 \%$, which was lower than the results of the present study. ${ }^{6}$ The results of the current study showed that $15.05 \%$ of the patients had influenza type $A$, which is higher than those reported in similar studies. Among patients with definite influenza A, $2.68 \%$ had $\mathrm{H} 1 \mathrm{~N} 1 / \mathrm{p}$ subtype and $4.57 \%$ had $\mathrm{H} 3 \mathrm{~N} 2$. It was also found that $0.63 \%$ had influenza type $\mathrm{B}$, which is lower than the results of the aforementioned studies.

The current study found that the most commonly prescribed drugs were ceftriaxone and vancomycin, which 
Table 3. Difference between Patients with Confirmed Influenza Virus Type A or B in Southern Iran (2015-2019)

\begin{tabular}{|c|c|c|c|c|}
\hline Variables & $\begin{array}{l}\text { Patients with Confirmed } \\
\text { Influenza }(n=199)\end{array}$ & $\begin{array}{l}\text { Patients with Confirmed } \\
\text { Influenza Type A }(n=191)\end{array}$ & $\begin{array}{l}\text { Patients with Confirmed } \\
\text { Influenza Type B }(\mathbf{n}=8)\end{array}$ & $P$ Value \\
\hline Age $($ Mean \pm SD) & $35.85 \pm 26.92$ & $35.27 \pm 26.81$ & $49.88 \pm 27.46$ & $0.133(95 \% \mathrm{Cl}=-33.70,4.489)$ \\
\hline \multicolumn{5}{|l|}{ Age groups (\%) } \\
\hline $0-1$ & $26(13.1)$ & $26(13.6)$ & $0(0)$ & \multirow{9}{*}{0.422} \\
\hline $2-4$ & $14(7.0)$ & $14(7.3)$ & $0(0)$ & \\
\hline $5-14$ & $21(10.6)$ & $20(10.5)$ & $1(12.5)$ & \\
\hline $15-24$ & $9(4.5)$ & $9(4.7)$ & $0(0)$ & \\
\hline $25-34$ & $29(14.6)$ & $27(14.1)$ & $2(25.0)$ & \\
\hline $35-44$ & $25(12.6)$ & $25(13.1)$ & $0(0)$ & \\
\hline $45-54$ & $18(9.0)$ & $16(8.4)$ & $2(25.0)$ & \\
\hline $55-64$ & $21(10.6)$ & $21(11.0)$ & $0(0)$ & \\
\hline$>65$ & $36(18.1)$ & $33(17.3)$ & $3(1.5)$ & \\
\hline \multicolumn{5}{|l|}{ Gender (\%) } \\
\hline Male & $103(51.8)$ & $101(52.9)$ & $2(25.0)$ & \multirow{3}{*}{0.158} \\
\hline Female & $96(48.2)$ & $90(47.1)$ & $6(75.0)$ & \\
\hline$P$ value & 0.713 & 0.497 & $<0.0001^{*}$ & \\
\hline \multicolumn{5}{|l|}{ History of travel (\%) } \\
\hline International & $10(5.0)$ & $10(5.03)$ & $0(0)$ & 0.848 \\
\hline Domestic & $7(3.5)$ & $6(3.14)$ & $1(12.5)$ & 0.668 \\
\hline History of contact to birds (\%) & $5(2.5)$ & $5(2.62)$ & $0(0)$ & 0.491 \\
\hline \multicolumn{5}{|l|}{ Comorbidities (\%) } \\
\hline Chronic heart diseases & $31(15.6)$ & $29(15.2)$ & $2(25)$ & 0.362 \\
\hline Diabetes & $20(10.1)$ & $19(9.9)$ & $1(12.5)$ & 0.578 \\
\hline Chronic pulmonary diseases & $17(8.5)$ & $16(8.4)$ & $1(12.5)$ & 0.517 \\
\hline Chronic nervous diseases & $9(4.5)$ & $9(4.7)$ & $0(0)$ & 1.0 \\
\hline Chronic liver diseases & $6(3.0)$ & $6(3.1)$ & $0(0)$ & 1.0 \\
\hline Chronic kidney diseases & $5(2.5)$ & $5(2.6)$ & $0(0)$ & 1.0 \\
\hline Pregnancy & $5(2.5)$ & $4(2.1)$ & $1(12.5)$ & 0.187 \\
\hline Malignancy & $2(1.0)$ & $1(0.5)$ & $1(12.5)$ & 0.79 \\
\hline Severe obesity & $2(1.0)$ & $2(1.0)$ & $0(0)$ & 1.0 \\
\hline Chronic blood diseases & $1(0.5)$ & $1(0.5)$ & $0(0)$ & 1.0 \\
\hline Malnutrition & $1(0.5)$ & $1(0.5)$ & $0(0)$ & 1.0 \\
\hline HIV/AIDS & $0(0)$ & $0(0)$ & $0(0)$ & - \\
\hline Without underlying diseases & $118(59.3)$ & $115(60.2)$ & $3(37.5)$ & 0.275 \\
\hline \multicolumn{5}{|l|}{ Complications (\%) } \\
\hline Pneumonia & $60(30.2)$ & $59(30.9)$ & $1(12.5)$ & 0.439 \\
\hline ARDS & $14(7.0)$ & $14(7.3)$ & $0(0)$ & 1.0 \\
\hline Cardiopulmonary & $7(3.5)$ & $7(3.7)$ & $0(0)$ & 1.0 \\
\hline Bronchitis & $7(3.5)$ & $7(3.7)$ & $0(0)$ & 1.0 \\
\hline Neurologic & $3(1.5)$ & $3(1.6)$ & $0(0)$ & 1.0 \\
\hline Without complications & $123(61.8)$ & $116(60.7)$ & $7(87.5)$ & 0.158 \\
\hline \multicolumn{5}{|l|}{ Prescribed drugs } \\
\hline Ceftriaxone & $57(28.6)$ & $53(27.7)$ & $4(50.0)$ & 0.229 \\
\hline Vancomycin & $35(17.6)$ & $35(18.3)$ & $0(0)$ & 0.355 \\
\hline Meropenem & $31(15.6)$ & $31(16.2)$ & $0(0)$ & 0.613 \\
\hline Azithromycin & $18(9.0)$ & $17(8.9)$ & $1(12.5)$ & 0.538 \\
\hline Amikacin & $4(2.0)$ & $4(2.1)$ & $0(0)$ & 1.0 \\
\hline Imipenem & $3(1.5)$ & $3(1.6)$ & $0(0)$ & 1.0 \\
\hline \multicolumn{5}{|l|}{ Patients' outcome (\%) } \\
\hline Outpatients & $62(31.2)$ & $60(31.4)$ & $2(25.0)$ & 0.9947 \\
\hline Inpatients & $131(65.8)$ & $125(65.4)$ & $6(75.0)$ & 0.857 \\
\hline Death & $6(3.0)$ & $6(3.1)$ & $0(0)$ & 0.578 \\
\hline
\end{tabular}

ARDS, Acute respiratory distress syndrome; HIV/AIDS, human immunodeficiency viruses/ acquired immunodeficiency syndrome

might be due to complications, especially pneumonia. Mozhgani et al reported that the most commonly prescribed drugs for patients with influenza were amantadine, zanamivir, and oseltamivir. ${ }^{6}$ Ziyaeyan et al found that all patients with $\mathrm{A} / \mathrm{H} 1 \mathrm{~N} 1$ were sensitive to oseltamivir. $^{24}$

In the present study, $31.2 \%$ of patients were hospitalized, which was lower than the rate reported by
Afrasiabian et al, and higher than that reported by Cutter et al. ${ }^{78}$ Unnecessary hospitalization results in financial and human resources losses in the healthcare systems; hence, physicians should be trained on the diagnosis of influenza in order to prevent unnecessary referrals. Also, the results of the current study showed that mortality in patients with definite influenza was $3.0 \%$, and there was no difference between types A and B in this regard. This 
Table 4. Association between Complications and Gender, Age Groups, History of International and Domestic Travel, as well as History of Contact with Birds in Patients with Influenza

\begin{tabular}{|c|c|c|c|c|c|c|}
\hline \multirow[b]{2}{*}{ Variables } & \multicolumn{5}{|c|}{ Complications } & \multirow[b]{2}{*}{$P$ Value } \\
\hline & $\begin{array}{c}\text { Pneumonia } \\
(\mathrm{n}=377)\end{array}$ & $\begin{array}{c}\text { ARD } \\
(n=84)\end{array}$ & $\begin{array}{c}\text { Bronchitis } \\
(n=55)\end{array}$ & $\begin{array}{l}\text { Cardiopulmonary } \\
\qquad(\mathrm{n}=62)\end{array}$ & $\begin{array}{l}\text { Neurologic } \\
(\mathbf{n}=39)\end{array}$ & \\
\hline \multicolumn{7}{|c|}{ Gender (\%) } \\
\hline Male & $167(44.3)$ & $44(52.4)$ & $24(43.6)$ & $42(67.6)$ & $20(51.3)$ & \multirow{3}{*}{$0.011^{*}$} \\
\hline Female & $210(55.7)$ & $40(47.6)$ & $31(56.4)$ & $20(32.3)$ & $19(48.7)$ & \\
\hline$P$ value & 0.063 & 0.439 & 0.479 & $0.002^{*}$ & 0.706 & \\
\hline \multicolumn{7}{|c|}{ Age groups (\%) } \\
\hline $0-1$ & $142(37.3)$ & $16(19.0)$ & $30(54.5)$ & $18(29.0)$ & $17(43.6)$ & \multirow{10}{*}{0.290} \\
\hline $2-4$ & $24(6.4)$ & $9(10.7)$ & $2(3.6)$ & $2(3.2)$ & $3(7.7)$ & \\
\hline $5-14$ & $48(12.7)$ & $6(7.1)$ & $9(16.4)$ & $5(8.1)$ & $8(20.5)$ & \\
\hline $15-24$ & $15(4.0)$ & $6(7.1)$ & $1(1.8)$ & $7(11.3)$ & $2(5.1)$ & \\
\hline $25-34$ & $32(8.5)$ & $7(8.3)$ & $1(1.8)$ & $2(3.2)$ & $3(7.7)$ & \\
\hline $35-44$ & $24(6.4)$ & $11(13.1)$ & $3(5.5)$ & $9(14.5)$ & $3(7.7)$ & \\
\hline $45-54$ & $18(4.8)$ & $7(8.3)$ & $1(1.8)$ & $3(4.8)$ & $1(2.6)$ & \\
\hline $55-64$ & $23(6.1)$ & $7(8.3)$ & $3(5.5)$ & 7 (11.3) & $2(5.1)$ & \\
\hline$>65$ & $51(13.5)$ & 15 (17.9) & $5(9.1)$ & $9(14.5)$ & $0(0)$ & \\
\hline$P$ value & $<0.0001^{*}$ & 0.466 & $<0.0001^{*}$ & 0.14 & 0.123 & \\
\hline \multicolumn{7}{|c|}{ History of international travel (\%) } \\
\hline Yes & $19(5.0)$ & $3(3.6)$ & $1(1.8)$ & $6(9.7)$ & $0(0)$ & \multirow{3}{*}{0.152} \\
\hline No & $358(95.0)$ & $81(96.4)$ & $54(98.2)$ & $56(90.3)$ & $39(100)$ & \\
\hline$P$ value & 0.629 & 0.619 & 0.361 & 0.141 & 0.129 & \\
\hline \multicolumn{7}{|c|}{ History of domestic travel (\%) } \\
\hline Yes & $13(3.4)$ & $3(3.6)$ & $4(7.3)$ & $3(4.8)$ & $2(5.1)$ & \multirow{3}{*}{0.720} \\
\hline No & $364(96.6)$ & $81(96.4)$ & $51(92.7)$ & $59(95.2)$ & $37(94.9)$ & \\
\hline$P$ value & 0.939 & 0.759 & 0.111 & 0.463 & 0.384 & \\
\hline \multicolumn{7}{|c|}{ History of contact with birds (\%) } \\
\hline Yes & $6(1.6)$ & $3(3.6)$ & $2(3.6)$ & $1(1.6)$ & $1(2.6)$ & \multirow{3}{*}{0.718} \\
\hline No & 371 (98.4) & $81(96.4)$ & $53(96.4)$ & $61(98.4)$ & $38(97.4)$ & \\
\hline$P$ value & 0.057 & 0.619 & 0.679 & 1.0 & 1.0 & \\
\hline
\end{tabular}

* Statistically significant.

Table 5. Outcome of Patients with Confirmed Influenza in Southern Iran (2015-2019)

\begin{tabular}{|c|c|c|c|c|c|}
\hline Age Groups & Outpatients (\%) & Inpatients (\%) & Death (\%) & Total $(\%)$ & $P$ Value \\
\hline $0-1$ & $16(12.2)$ & $10(16.1)$ & $0(0)$ & $26(13.1)$ & \multirow{10}{*}{$0.036^{*}$} \\
\hline $2-4$ & $9(6.9)$ & $5(8.1)$ & $0(0)$ & $14(7.0)$ & \\
\hline $5-14$ & $17(13.0)$ & $4(6.5)$ & $0(0)$ & $21(10.6)$ & \\
\hline $15-24$ & $7(5.3)$ & $2(3.2)$ & $0(0)$ & $9(4.5)$ & \\
\hline $25-34$ & $17(13.0)$ & $11(17.7)$ & $1(16.7)$ & $29(14.6)$ & \\
\hline $35-44$ & $18(13.7)$ & $3(4.8)$ & $4(66.7)$ & $25(12.6)$ & \\
\hline $45-54$ & $13(9.9)$ & $5(8.1)$ & $0(0)$ & $18(9.0)$ & \\
\hline $55-64$ & $10(7.6)$ & $10(16.1)$ & $1(16.7)$ & $21(10.6)$ & \\
\hline$>65$ & $24(18.3)$ & $12(19.4)$ & $0(0)$ & $36(18.1)$ & \\
\hline Total & $131(65.8)$ & $62(31.2)$ & $6(3.0)$ & 199 & \\
\hline
\end{tabular}

* Statistically significant.

rate was reported at $3.8 \%$ by Gouya et al. ${ }^{21}$ The mortality rate in the current study was higher than the reported results of Haghshenas et al and Yavarian et al. ${ }^{15,26}$ Contrary to the results of the present study, Mozhgani et al reported that $\mathrm{A} / \mathrm{H} 1 \mathrm{~N} 1$ had the highest mortality than the other subtypes. ${ }^{6}$ The reported mortality rate of $\mathrm{A} / \mathrm{H} 1 \mathrm{~N} 1$ is even lower in some countries. ${ }^{27-29}$

The results of the current study showed that fever and dyspnea were the most frequent symptoms associated with influenza. The results of various studies show that the frequency of symptoms is different. Most studies reported fever and cough as the most common symptoms. ${ }^{14,18,27,29}$ Also, our result indicated that chronic heart disease and diabetes were the most prevalent comorbidities in our patients, but Yacarian et al reported asthma and diabetes, as well cardiovascular disease as the most common underlying diseases in patients who expired. ${ }^{15}$

The strength of our study is using a large database, the Syndromic Surveillance System of Iran's health ministry, which records data from all patients who were referred to one of the Health Centers in the Fars province. Lack of complete records of patients' information in this system 
was one of the limitations of the current study. As this disease is self-limited in most of the patients, ${ }^{8}$ a large proportion of infected population are not registered in health centers and the statistical estimation may not perfectly reflect the reality.

In conclusion, the results showed that the incidence of influenza, especially type A in the Fars province, southern Iran is considerable and requires more attention for prevention in health policy programs.

\section{Authors' Contribution}

Study concept and design: $\mathrm{HF}, \mathrm{AH}, \mathrm{HB}$; Data gathering: $\mathrm{HF}, \mathrm{AH}$, $A F$, HB; Data analysis: RSMR; Writing manuscript: HF, RSMR, $\mathrm{AH}, \mathrm{AF}, \mathrm{HB}$; Revise manuscript: HF, RSMR, AH, AF, HB; Approve manuscript: $\mathrm{HF}, \mathrm{RSMR}, \mathrm{AH}, \mathrm{AF}, \mathrm{HB}$.

\section{Conflict of Interest Disclosures}

None declared.

\section{Ethical Statement}

The current study was conducted in accordance with the Declaration of Helsinki, and it was approved by the vice-chancellor of research and technology, as well as the local ethics committee of Shiraz University of Medical Sciences (IR.sums.med.rec.1397.472). To consider ethical issue, the collected data were not revealed to anyone, except for the researchers; hence, patients' names were kept confidential.

\section{Acknowledgements}

The current study was extracted from the thesis for the degree of medical doctor, which was approved and financially supported by Shiraz University of Medical Sciences (grant No. 17669).

\section{Supplementary Materials}

Supplementary file 1 contains Table S1.

\section{References}

1. Neumann G, Brownlee GG, FodorE, KawaokaY. Orthomyxovirus replication, transcription, and polyadenylation. Curr Top Microbiol Immunol. 2004; 283:121-43. doi: 10.1007/978-3662-06099-5 4 .

2. Cox NJ, Subbarao K. Global epidemiology of influenza: past and present. Annu Rev Med. 2000;51:407-21. doi: 10.1146/ annurev.med.51.1.407.

3. Zambon MC. Epidemiology and pathogenesis of influenza. J Antimicrob Chemother. 1999;44 Suppl B:3-9. doi: 10.1093/ jac/44.suppl_2.3.

4. Webster RG, Govorkova EA. Continuing challenges in influenza. Ann N Y Acad Sci. 2014;1323(1):115-39. doi: 10.1111/nyas.12462.

5. Caini S, El-Guerche Séblain C, Ciblak MA, Paget J. Epidemiology of seasonal influenza in the Middle East and North Africa regions, 2010-2016: Circulating influenza A and $B$ viruses and spatial timing of epidemics. Influenza Other Respir Viruses. 2018;12(3):344-352. doi: 10.1111/irv.12544.

6. Mozhgani SH, Zarei Ghobadi M, Moeini S, Pakzad R, Kananizadeh P, Behzadian F. Prevalence of human influenza virus in Iran: Evidence from a systematic review and metaanalysis. Microb Pathog. 2018;115:168-174. doi: 10.1016/j. micpath.2017.

7. Cutter JL, Ang LW, Lai FY, Subramony H, Ma S, James L. Outbreak of pandemic influenza A (H1N1-2009) in Singapore, May to September 2009. Ann Acad Med Singapore. 2010;39(4):273-10.

8. Afrasiabian S, Mohsenpour B, Bagheri KH, Barari M, Ghaderi $\mathrm{E}$, Hashemi R, et al. Epidemiological survey on pandemic influenza A (H1N1) virus infection in Kurdistan province, Islamic Republic of Iran, 2009. East Mediterr Health J. 2014;20(3):169-74.

9. Beigel JH. Influenza. Crit Care Med. 2008;36(9):2660-6. doi: 10.1097/CCM.0b013e318180b039.

10. Gianella A, Walter A, Revollo R, Loayza R, Vargas J, Roca Y. Epidemiological analysis of the influenza $A(H 1 N 1)$ v outbreak in Bolivia, May-August 2009. Euro Surveill. 2009;14(35):19323.

11. Javid N, Moradi A, Tabarraei A, Bazouri M. Clinical and Epidemiological Profile of Pandemic Influenza A H1N1, H3N2, and Type B in the Southeast of Caspian Sea, Iran. Jundishapur J Microbiol. 2017;10(3):1.

12. Javid Khojasteh V, Mojtahedi A, Hosseini S, Joukar F. Relative frequency of influenza A/H1N1 virus in Guilan province, Iran. Iran J Med Microbiol. 2017;11(5):83-89.

13. Haghshenas $M$, Jafarian $E$, Babamahmoodi $F$, Tabrizi $A$, Nandoost S, Alizadeh-Navaei R. Prevalence of influenza A/ H3N2 virus in northern Iran from 2011 to 2013. Caspian J Intern Med. 2015;6(2):116-9.

14. Rahmanian $\mathrm{V}$, Shakeri $\mathrm{M}$, Shakeri $\mathrm{H}$, Jahromi AS, Bahonar $\mathrm{A}$, Madani A. Epidemiology of Influenza in Patients with Acute Lower Respiratory Tract Infection in South of Iran (2015-2016). Acta facultatis medicae Naissensis. 2019;36(1):27-37.

15. Yavarian J, Naseri M, Shadab A, Shafiei Jandaghi NZ, Mokhtari Azad T. Epidemiological aspects of pandemic influenza $\mathrm{A}(\mathrm{H} 1 \mathrm{~N} 1)$ virus from 2009 to 2011 in Iran. Influenza Other Respir Viruses. 2012;6(6):e74-6. doi: 10.1111/j.17502659.2012.00357.x

16. Ling LM, Chow AL, Lye DC, Tan AS, Krishnan P, Cui L, et al. Effects of early oseltamivir therapy on viral shedding in 2009 pandemic influenza A (H1N1) virus infection. Clin Infect Dis. 2010;50(7):963-9. doi: 10.1086/651083.

17. Lozano R, Naghavi M, Foreman K, Lim S, Shibuya K, Aboyans $V$, et al. Global and regional mortality from 235 causes of death for 20 age groups in 1990 and 2010: a systematic analysis for the Global Burden of Disease Study 2010. Lancet. 2012;380(9859):2095-128. doi: 10.1016/S01406736(12)61728-0.

18. Zaman RU, Alamgir AS, Rahman M, Azziz-Baumgartner E, Gurley ES, Sharker MA, et al. Influenza in outpatient ILI casepatients in national hospital-based surveillance, Bangladesh, 2007-2008. PLoS One. 2009;4(12):e8452. doi: 10.1371/ journal.pone.0008452.

19. Moghadami M, Kazeroni PA, Honarvar B, Ebrahimi M, Bakhtiari H, Akbarpour MA, et al. Influenza A (H1N1) virus pandemic in Fars province: a report from southern Iran, JulyDecember 2009. Iran Red Crescent Med J. 2010;12(3):231.

20. Moasser E, Behzadian F, Moattari A, Fotouhi F, Zaraket H. Characterization of the neuraminidase genes from human influenza A viruses circulating in Iran from 2010 to 2015. Arch Virol. 2018;163(2):391-400. doi: 10.1007/s00705-0173603-y.

21. Gouya MM, Nabavi M, Soroush M, Haghdoust AA, Ghalehee $\mathrm{S}$, Hemmati $\mathrm{P}$, et al. Mortality from Pandemic Influenza A (H1N1) in Iran. Iran Red Crescent Med J. 2011;13(10):698701.

22. Chakhunashvili G, Wagner AL, Machablishvili A, Karseladze I, Tarkhan-Mouravi O, Zakhashvili K, et al. Implementation of a sentinel surveillance system for influenza-like illness (ILI) and severe acute respiratory infection (SARI) in the country of Georgia, 2015-2016. Int J Infect Dis. 2017;65:98-100. doi: 10.1016/j.ijid.2017.09.028.

23. Belderok SM, Rimmelzwaan GF, van $\operatorname{den} \operatorname{Hoek} A$, Sonder GJ. Effect of travel on influenza epidemiology. Emerg Infect Dis. 2013;19(6):925-31. doi: 10.3201/eid1906.111864.

24. Ziyaeyan M, Alborzi A, Jamalidoust M, Moeini M, Pouladfar 
GR, Pourabbas B, et al. Pandemic 2009 influenza A (H1N1) infection among 2009 Hajj Pilgrims from Southern Iran: a real-time RT-PCR-based study. Influenza Other Respir Viruses. 2012;6(6):e80-4. doi: 10.1111/j.1750-2659.2012.00381.x.

25. Haghshenas, MR, Hosseini, E, Babamahmoodi, F, NandoustKenari, Sh, Tabrizi, A. Prevalence of Influenza B Virus in Flu Patients Referring to Health Centers in Mazandaran Province, Iran, 2011- 2013. mljgoums. 2015; 9 (3) :122-127. Available from: URL: http://mlj.goums.ac.ir/article-1-753-

26. Haghshenas M, Mousanejad P, Aarabi M, Rabie-Rudsari M, Rasouli-Larmaei S. Prevalence of Influenza A/H1N1 Virus in North of Iran, 2013 to 2017. J Mazandaran Univ Med Sci.
2019;29(177):148-156.

27. Gianella A, Walter A, Revollo R, Loayza R, Vargas J, Roca Y. Epidemiological analysis of the influenza $A(\mathrm{H} 1 \mathrm{~N} 1)$ v outbreak in Bolivia, May-August 2009. Euro Surveill. 2009;14(35):19323..

28. Ciblak MA, Albayrak N, Odabas Y, Basak Altas A, Kanturvardar M, Hasoksuz M, et al. Cases of influenza A (H1N1) reported in Turkey, May-July 2009. Euro Surveill. 2009;14(32):19304. Erratum in: Euro Surveill. 2009;14(33):19313.

29. Ou Q, LuY, Huang Q, Cheng X. Clinical analysis of 150 cases with the novel influenza A (H1N1) virus infection in Shanghai, China. Biosci Trends. 2009;3(4):127-30. 